
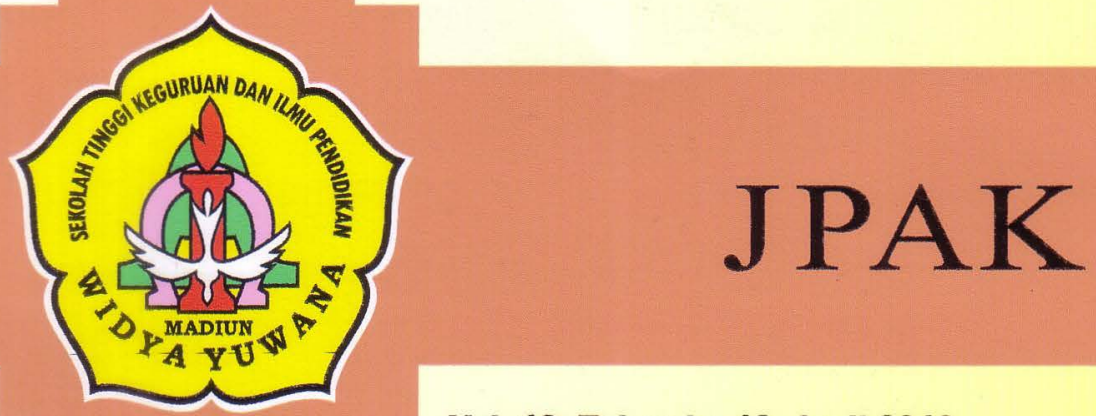

Vol. 19, Tahun ke-10, April 2018

ISSN; 2085-0743

MEMBANGUN SISTEM PENDIDIKAN MULTIKULTURAL DI INDONESIA Oleh: Natalis Sukma Permana

PENDIDIKAN MULTIKULTURAL DI INDONESIA: ARAH DAN MANFAATNYA Oleh: Ola Rongan Wilhelmus

ORANGTUA DAN PENDIDIKAN ANAK DALAM PERSPEKTIF GRAVISSIMUM EDUCATIONIS DAN RELEVANSINYA BAGI SISTEM PENDIDIKAN DI INDONESIA Oleh: Agustinus Supriyadi

PENELITIAN TERHADAP MINAT MENJADI GURU AGAMA DAN KATEKIS DI STKIP WIDYA YUWANA MADIUN Oleh: Agustinus Wisnu Dewantara dan Natalis Sukma Permana

KERASULAN AWAM DAN TRANSFORMASI MASYARAKAT Oleh: Kurdo Irianto

ORANG MUDA DAN PENGEMBANGAN SOSIAL EKONOMI MENURUT PAUS FRANSISKUS Oleh: Alphonsus Boedi Prasetijo

PARTISIPASI UMAT BERIMAN SEBAGAI PENGURUS DEWAN PASTORAL PAROKI PERIODE 2015-2018 DI PAROKI REGINA PACIS MAGETAN Oleh: Bryan Michael Wijaya dan Don Bosco Karnan Ardijanto

HUBUNGAN PACARAN DENGAN PENINGKATAN MOTIVASI DAN PRESTASI BELAJAR MAHASISWA STKIP WIDYA YUWANA MADIUN Oleh: Priska Rabu dan Wilhelmus Ola Rongan

\title{
Lembaga Penelitian
}

Sekolah Tinggi Keguruan dan IImu Pendidikan "Widya Yuwana" MADIUN 


\section{JPAK}

Vol. 19, Tahun ke-10, April 2018

ISSN; 2085-0743

\section{DAFTAR ISI}

3 MEMBANGUN SISTEM PENDIDIKAN MULTIKULTURAL DI INDONESIA

Oleh: Natalis Sukma Permana

13 PENDIDIKAN MULTIKULTURALDI INDONESIA:ARAH DAN MANFAATNYA

Oleh: Ola Rongan Wilhelmus

27 ORANGTUA DAN PENDIDIKAN ANAK DALAM PERSPEKTIF GRAVISSIMUM EDUCATIONIS DAN RELEVANSINYA BAGI SISTEM PENDIDIKAN DI INDONESIA

Oleh: Agustinus Supriyadi

39 PENELITIANTERHADAP MINAT MENJADI GURU AGAMA DAN KATEKIS DI STKIP WIDYA YUWANA MADIUN

Oleh: Agustinus Wisnu Dewantara dan Natalis Sukma Permana

50 KERASULAN AWAM DAN TRANSFORMASI MASYARAKAT

Oleh: Kurdo Irianto

60 ORANG MUDA DAN PENGEMBANGAN SOSIAL EKONOMI MENURUT PAUS FRANSISKUS

Oleh: Alphonsus Boedi Prasetijo

70 PARTISIPASI UMAT BERIMAN SEBAGAI PENGURUS DEWAN PASTORAL PAROKI PERIODE 2015-2018 DI PAROKI REGINA PACIS MAGETAN

Oleh: Bryan Michael Wijaya dan Don Bosco Karnan Ardijanto

90 HUBUNGAN PACARAN DENGAN PENINGKATAN MOTIVASI DAN PRESTASI BELAJAR MAHASISWA STKIPWIDYAYUWANA MADIUN

Oleh: Priska Rabu dan Wilhelmus Ola Rongan 


\author{
Oleh: \\ Natalis Sukma Permana \\ STKIP Widya Yuwana Madiun
}

\title{
Abstract
}

Education is one of the elements of character building and human self-development. Education is expected to provide learning so that learners are able to understand themselves, others, the community environment and all the differences that exist in the environment and be tolerant to all the differences that exist in society. Multicultural education is expected to be one of the ways in which learners develop tolerant attitudes toward different racial, ethnic, social and cultural groups, religions, etc.

According to UU No. 20 Year 2003 about the National Education System mentions "Education is conducted in a democratic and fair and nondiscriminatory way by upholding human rights, religious values, cultural values, and national pluralism". From article 4 it can be concluded that multicultural education becomes one of the attention in the national education system in Indonesia. Through a multicultural education, learners are able to appreciate the diversity of cultural diversity that exists in Indonesia, increasing the spirit of tolerance to the differences given that the culture of Indonesian society is very diverse.

Multicultural education is given to learners in the hope that they have the knowledge and understanding that in the country Indonesia is synonymous with plurality and prone to conflict. Multicultural education is expected to reduce the potential for conflict caused by various pluralism. Through the integration of curriculum and approaches in the learning process. In this case the 
school has a significant role in supporting the formation of a multicultural education society culture while the teacher also has a role in integrating and linking materials that lead to understanding and awareness of multiculturalism in Indonesia. Through multicultural education, learners are expected to have good competence, to behave and apply democratic values, humanism and pluralism in school and out of school. Thus, multicultural education system will be very possible to held with the cooperation of various parties that support the education process in Indonesia.

Keywords: multicultural, multicultural education, multicultural education system

\section{PENDAHULUAN}

Pendidikan merupakan salah satu unsur pembentukan karakter dan perkembangan diri manusia. Kesadaran masyarakat akan pentingnya pendidikan bagi peserta didik perlu ditingkatkan, mengingat pendidikan merupakan salah satu unsur yang melekat pada diri manusia sebagai hak yang harus diterimanya, serta pendidikan akan membawa masyarakat itu sendiri menuju kepada kemajuan, baik kemajuan dalam politik, ekonomi, sosial, dan budaya. Kemajuan yang diharapkan oleh masyarakat yaitu ketentraman, kerukunan, serta terhindar dari berbagai macam bentuk konflik.

Pendidikan diharapkan mampu memberikan wawasan baru yang dapat menciptakan budaya baru dan bersikap toleran terhadap budaya yang lain, maka pendidikan berbasis multikultural akan menjadi salah satu jalan untuk menanamkan sikap toleransi terhadap budaya yang dimiliki oleh bangsa Indonesia dan memberikan pembelajaran agar peserta didik mampu memahami dirinya, orang lain, lingkungan masyarakat serta segala perbedaan yang ada di lingkungannya dan bersikap toleran kepada semua perbedaan yang ada di lingkungan masyarakat.

UU No. 20 Tahun 2003, menegaskan fungsi dan tujuan pendidikan nasional. Pasal 3 menegaskan bahwa pendidikan nasional berfungsi mengembangkan kemampuan dan membentuk watak serta peradaban bangsa yang bermartabat dalam rangka mencerdaskan kehidupan bangsa, bertujuan untuk berkembangnya potensi peserta 
didik agar menjadi manusia yang beriman dan bertakwa kepada Tuhan Yang Maha Esa, berakhlak mulia, sehat, berilmu, cakap, kreatif, mandiri, dan menjadi warga negara yang demokratis serta bertanggung jawab.

Sebenarnya pemerintah Indonesia sudah memberikan ruang yang cukup untuk terselenggaranya pendidikan nasional yang sesuai dengan kebhinekaan bangsa Indonesia. Namun, masih banyak orang yang belum menyadari bahwa kemajemukan adalah sebuah kekayaan bangsa yang harus dipelihara dan dijaga keutuhannya. Kemajemukan sangat rawan dengan konflik, baik itu tentang isu SARA atau menyangkut status sosial sehingga menyebabkan hilangnya rasa persatuan dan rasa kemanusiaan. Salah satu upaya untuk mengatasi potensi-potensi konflik terkait kemajemukan tersebut harus dilakukan melalui pendidikan dengan cara membangun kultur pendidikan nilai di sekolah. Pendidikan memiliki peran yang sangat penting dalam membentuk manusia yang multikultural. Oleh karena itu, dibutuhkan langkah sistematis di dalam menerapkan dan merancang sebuah pendidikan multikultural melalui jalur pendidikan di sekolah.

\section{PENDIDIKAN}

Secara sederhana pendidikan dapat dimaknai sebagai sebuah usaha manusia untuk memperbaiki kepribadiannya sesuai degan nilai-nilai dan kebudayaannya. Pendidikan dapat dikatakan sebagai sebuah usaha manusia untuk melestarikan dan meningkatkan hidupnya. Menurut Ki Hajar Dewantara, pendidikan sebagai upaya untuk memajukan budi pekerti, pikiran serta jasmani anak, agar dapat memajukan kesempurnaan hidup dan menghidupkan anak yang selaras dengan alam dan masyarakatnya.

Pendidikan merupakan proses pengembangan sikap dan tata laku seseorang atau sekelompok orang dalam usaha mendewasakan manusia melalui pengajaran, pelatihan, proses, perbuatan dan caracara yang mendidik. Disisi lain pendidikan adalah transfer of knowledge atau memindah ilmu pengetahuan. Sedangkan multikultural secara etimologis multi berarti banyak, beragam dan aneka, sedangkan kultural berasal dari kata culture yang mempunyai makna budaya, tradisi multikultural memberikan arti secara terminologis adalah proses pengembangan seluruh potensi manusia yang menghargai pluralitas dan heterogenitasnya 
sebagai konsekuensi keragaman budaya, etnis, suku dan aliran (agama).

\subsection{Pendidikan Multikultural di Indonesia}

Multikultural berarti beranekaragam kebudayaan. Sedangkan multikulturalisme secara sederhana dapat diartikan sebagai pengakuan atas pluralisme budaya. Akar dari multikulturalisme adalah kebudayaan, yaitu kebudayaan yang dilihat dari fungsinya sebagai pedoman bagi kehidupan manusia. Dalam konteks pembangunan bangsa, istilah multikultural ini telah membentuk suatu ideologi yang disebut multikulturalisme. Multikulturalisme adalah berbagai pengalaman yang membentuk persepsi umum terhadap usia, gender, agama, status sosial ekonomi, jenis identitas budaya, bahasa, ras, dan berkebutuhan khusus.

Menurut UU No. 20 Tahun 2003 tentang Sistem Pendidikan Nasional pasal 1 ayat 1 , pendidikan merupakan usaha sadar dan terencana untuk mewujudkan suasana belajar dan proses pembelajaran agar peserta didik secara aktif mengembangkan potensi dirinya untuk memiliki kekuatan spiritual keagamaan, pengendalian diri, kepribadian, kecerdasan, akhlak mulia, serta keterampilan yang diperlukan dirinya, masyarakat, bangsa dan negara. Sedangkan pada Pasal 4 ayat (1) UU No. 20 tahun 2003 tentang Sistem Pendidikan Nasional menyebutkan "Pendidikan diselenggarakan secara demokratis dan berkeadilan serta tidak diskriminatif dengan menjunjung tinggi hak asasi manusia, nilai keagamaan, nilai kultural, dan kemajemukan bangsa". Dari pasal 4 ini dapat ditarik kesimpulan bahwa pendidikan multukultural menjadi salah satu perhatian di dalam sistem pendidikan nasional di Indonesia.

Dalam pelaksanaannya pendidikan multukultur secara rinci telah diuraikan dalam undang-undang sisdiknas pada pasal 4, yaitu: 1) Pendidikan diselenggarakan secara demokratis dan berkeadilan serta tidak diskriminatif dengan mejunjung tinggi hak asasi manusia, nilai keagamaan, nilai kultural, dan kemajemukan bangsa, 2) Pendidikan diselenggarakan sebagai satu kesatuan yang sistemik dengan sistem terbuka dan multimakna, 3) Pendidikan diselenggarakan sebagai suatu proses pembudayaan dan pemberdayaan peserta didik yang berlangsung sepanjang hayat, 4) Pendidikan diselenggarakan dengan memberi keteladanan, membangun kemauan, dan mengembangkan kreativitas peserta didik dalam proses pembelajaran, 5) Pendidikan diselenggarakan dengan 
mengembangkan budaya membaca, menulis, dan berhitung bagi segenap warga masyarakat, 6) Pendidikan diselenggarakan dengan memberdayakan semua komponen masyarakat melalui peran serta dalam penyelenggaraan dan pengendalian mutu layanan pendidikan.

Dari paparan di atas, pendidikan multikultural dapat dimaknai sebagai usaha sadar untuk mengembangkan kepribadian didalam dan diluar sekolah yang mempelajari tentang berbagai macam status sosial, ras, suku, agama agar tercipta kepribadian yang cerdas dalam menghadapi masalah-masalah keberagaman budaya. Pendidikan multikultur juga sudah tercantum dalam cita-cita pendidikan nasional di Indonesia, dan diharapkan mampu memberikan sebuah interpretasi yang positif terkait keberagaman yang ada di Indonesia.

\subsection{Pentingnya Pendidikan Multikultural di Indonesia}

Indonesia adalah negara yang kaya dengan berbagai keragaman baik dari suku, agama, budaya, ras, dan golongan. Keragaman tersebut dapat memicu sikap primordialisme ataupun dapat memicu konflik. Kemajemukan dan keberagaman di Indonesia dapat dilihat dari dua pandangan, yaitu: perspektif horizontal dan dan vertikal. Perspektif horizontal, kemajemuan bangsa dapat dilihat dari perbedaan agama, etnis, bahasa daerah, geografis, dan budayanya. Perspektif vertikal, kemajemukan bangsa Indonesia dapat dilihat dari perbedaan tingkat pendidikan, ekonomi, dan tingkat sosial budayanya (Arifin, 2012:77).

Dalam menghadapi perbedaan tersebut, menjadi sangat penting untuk menanamkan kesadaran multukultur bagi masyarakat Indonesia terutama kepada peserta didik. Adapun pentingnya pendidikan multikultural menurut Zamroni (2011:33) adalah sebagai berikut:

a. Pendidikan multikultural adalah jantung untuk menciptakan kesetaraan pendidikan bagi seluruh warga masyarakat;

b. Pendidikan multikultural bukan sekedar perubahan kurikulum atau perubahan metode pembelajaran;

c. Pendidikan multikultur mentrasformasi kesadaran yang memberikan arah kemana transformasi praktik pendidikan;

d. Pendidikan multikultural bertujuan untuk berbuat sesuatu, yaitu membangun jembatan antara kurikulum dan karakter guru, pedagogi, iklim kelas, dan kultur sekolah guna membangun visi sekolah yang menjunjung kesetaraan. 
Oleh karena itu untuk memunculkan sikap toleransi dan sikap saling menghargai lintas budaya, maka perlu diberlakukan sistem pendidikan yang multikultur. Pendidikan multikultur ini mempunyai peran yang sangat strategis dalam membekali seseorang menghadapi era globalisasi sehingga tidak hanyut dalam dampak negatif globalisasi (Indrapengestuti, 2014:18).

Melalui sebuah pendidikan multikultur, peserta didik diharapkan mampu menghargai keberagaman budaya yang ada di Indonesia, meningkatkan semangat toleransi terhadap perbedaan, mengingat bahwa kultur masyarakat Indonesia sangat beragam. Di era yang modern ini keberagaman justru bisa dilihat sebagai sebuah pemecah persatuan bangsa. Oleh karena itu pendidikan multikultur diharapkan mampu untuk membina peserta didik untuk semakin memahami budayanya sesuai dengan cita-cita pendidikan nasional.

\section{IMPLEMENTASI PENDIDIKAN MULTIKULTURAL MELALUI PENDIDIKAN DI SEKOLAH}

Pendidikan multikultur di Indonesia dapat dilaksanakan secara fleksibel dengan tetap mengutamakan prinsip multikultur dan tujuan pendidikan nasional di Indonesia. Sekolah sebagai salah satu lembaga formal pelaksanaan pendidikan harus dipandang sebagai gambaran dari masyarakat di Indonesia. Agar pendidikan multikultur dapat terlaksana di Indonesia, maka diperlukan sebuah sinergi mulai dari kurikulum, materi ajar yang lebih menekankan persatuan budaya di Indonesia, atau dengan mengadakan kegiatan yang mencirikan kebudayaan masing-masing daerah di Indonesia. Oleh karena itu, para pendidik diharapkan mampu menanamkan kepada peserta didik agar mereka memiliki sikap toleransi, cinta kepada kebudayaan yang lain.

Dalam kehidupan yang beragam seperti ini, menjadi tantangan untuk mempersatukan bangsa Indonesia menjadi satu kekuatan yang dapat menjunjung tinggi perbedaan dan keragaman masyarakatnya. Hal ini dapat dilakukan dengan pendidikan multikultural yang ditanamkan kepada anak-anak lewat pembelajaran di sekolah maupun di rumah. Pendidik bertanggung jawab dalam memberikan pendidikan terhadap anak didiknya dan dibantu oleh orang tua dalam melihat perbedaan yang terjadi dalam kehidupan mereka sehari-hari. Namun pendidikan multikultural bukan hanya sebatas kepada anakanak usia sekolah, tetapi juga kepada masyarakat Indonesia pada 
umumnya lewat acara atau seminar yang menggalakkan pentingnya toleransi dalam keberagaman menjadikan masyarakat Indonesia dapat menerima bahwa mereka hidup dalam perbedaan dan keragaman.

Pendidikan multikultural memang sebuah konsep yang dibuat dengan tujuan untuk menciptakan persamaan peluang pendidikan bagi semua siswa yang berbeda ras, etnis, kelas sosial dan kelompok budaya. Salah satu tujuan penting dari konsep pendidikan multikultural adalah untuk membantu semua siswa agar memperoleh pengetahuan, sikap dan ketrampilan yang diperlukan dalam menjalankan peran-peran se-efektif mungkin pada masyarakat demokrasi-pluralistik serta diperlukan untuk berinteraksi, negosiasi, dan komunikasi dengan warga dari kelompok beragam, agar tercipta sebuah tatanan masyarakat bermoral yang berjalan untuk kebaikan bersama. Dalam implementasinya, paradigma pendidikan multikultural dituntut untuk berpegang pada prinsip-prinsip berikut ini:

1. Pendidikan multikultural harus menawarkan beragam kurikulum yang merepresentasikan pandangan dan perspektif banyak orang.

2. Kurikulum dicapai sesuai dengan penekanan analisis komparatif dengan sudut pandang kebudayaan yang berbeda-beda.

3. Pendidikan multikultural harus mendukung prinsip-prinisip pokok dalam memberantas pandangan tentang perbedaan ras, budaya dan agama.

Menurut Gordyn dan Robert (Sutarno, 2008:7) ada beberapa prinsip yang digunakan untuk menyeleksi materi pokok untuk pembelajaran multikultur yaitu sebagai berikut:

1. Seleksi materi pokok bahasan disesuaikan seharusnya mencantumkan hal-hal kultural dan didasarkan pada keilmuan masakini.

2. Materi pokok bahasan yang akan dicantumkan seharusnya mempresentasikan keagamaan dalam konteks dan waktu dan tempat.

3. Perspektif budaya seharusnya bisa dimasukkan di dalam keseluruhan kurikulum.

Sejalan dengan beberapa hal di atas menurut Bank (2007: 83-85) memberikan panduan dimana ada lima dimensi pendidikan multikultur yang seharusnya secara simultan dilakukan, yaitu: integrasi materi (content integration), proses pembentukan pengetahuan (knowledge construction process), reduksi prasangka (prejudice reduction), pendidikan/perlakuan pedagogi tanpa pandang 
bulu (equity pedagogy), dan pemberdayaan budaya sekolah dan struktur sosial (empowering school culture and social structure).

Integrasi materi adalah upaya guru untuk memberikan contohcontoh, mengajarkan konsep, prinsip pendidikan multikultural. Misalkan guru sedang mengajarkan materi pendidikan agama Katolik untuk kelas XII dengan tema "keberagaman sebagai realitas asali kehidupan manusia" atau "dialog antar umat beragama dan kepercayaan lain", dalam hal ini guru dapat menambahkan beberapa tambahan kemajemukan agama yang ada di Indonesia.

Dimensi ini berupaya membantu peserta didik untuk memahami, mencari tahu, dan menentukan bagaimana suatu pengetahuan atau teori pada dasarnya secara implisit tercipta karena adanya pengaruh budaya tertentu, kalangan tertentu, kelompok dengan status sosial tertentu yang terjadi pada saat itu. Misalkan seseorang yang mencuri harus dihukum rajam atau dihukum mati. Di sini guru harus menjelaskan mengapa hal itu sampai terjadi dengan mengungkapkan pengaruh budaya masyarakat di sana pada waktu itu.

Reduksi adalah upaya guru membantu peserta didik mengembangkan sikap positif terhadap perbedaan baik dari sisi suku, budaya, ras, gender, status sosial, dll. Misalkan dalam materi pelajaran agama Katolik dengan tema "membangun bangsa dan negara dengan semangat kristiani" di sini seorang guru dapat menumbuhkan sikap-sikap positif dengan adanya perbedaanperbedaan yang ada di Indonesia. Dalam hal ini adalah tidak benar jika seorang guru justru memicu timbulnya konflik diantara para peserta didik dikarenakan adanya beberapa perbedaan dari sisi bahasa, warna kulit, atau asal daerah.

Perlakuan pedagogik tanpa pandang bulu (equity pedagogy) adalah upaya guru memperlakukan secara sama tanpa pandang bulu dalam proses pembelajaran di kelas. Hal ini dapat diimplementasikan dalam proses pembelajaran misalkan dengan menggunakan strategi cooperative learning. Model pembelajaran ini dapat terlihat dari cara pembagian siswa, tugas belajar, sehingga dapat mengurangi perasaan dibedakan-bedakan karena jenis golongan, agama, atau ras.

Pendidikan multikultural mencerminkan keseimbangan antara pemahaman persamaan dan perbedaan budaya mendorong individu untuk mempertahankan dan memperluas wawasan budaya dan kebudayaan mereka sendiri. Beberapa aspek yang menjadi kunci dalam melaksanakan pendidikan multikultural dalam struktur sekolah adalah tidak adanya kebijakan yang menghambat toleransi, 
termasuk tidak adanya penghinaan terhadap suku, agama, ras, dan kebudayaan. Pendidikan multikultural harus menumbuhkan kepekaan terhadap perbedaan budaya, diantaranya mencakup pakaian, musik dan makanan kesukaan. Selain itu, juga memberikan kebebasan bagi anak dalam merayakan hari-hari besar umat beragama serta memperkokoh sikap anak agar merasa butuh terlibat dalam pengambilan keputusan secara demokratis. Pendidikan multikultur akan berhasil jika seluruh elemen pendidikan bekerjasama mewujudkan terlaksananya pendidikan multikultur. Implementasi pendidikan multikultur di Indonesia adalah, penyiapan kurikulum, yakni menyisipkan berbagai kompetensi yang harus dimiliki siswa tentang multikulturalisme pada mata pelajaran yang relevan, karena multikulturalisme baru sebuah gerakan dan belum menjadi sebuah ilmu yang komprehensif(Rosyada, 2014:4).

\section{PENUTUP}

Dari beberapa hal di atas, dapat ditarik sebuah kesimpulan bahwa pendidikan multikultural sangat penting diterapkan di Indonesia. Mengingat bahwa negara Indonesia kaya dengan berbagai kemajemukan. Pendidikan multikultural dapat dijadikan sebagai sebuah alternatif untuk mengembangkan kebanggaan seseorang terhadap bangsanya. Dalam menghadapi keberagaman budaya, diperlukan paradigma baru yang lebih toleran dan elegan untuk mencegah dan memecahkan masalah benturan-benturan dari segala perbedaan suku, bahasa, agama, ras, budaya, dll. Oleh karena itu praktik pendidikan multikultural di Indonesia dapat dilaksanakan secara fleksibel dengan mengutamakan prinsip-prinsip dasar multikultural salah satunya melalui proses pembelajaran.

Pendidikan multikultural juga sangat relevan dengan pendidikan demokrasi di masyarakat plural seperti Indonesia yang menekankan pada pemahaman akan multietnis, multi ras, dan multikultur yang memerlukan konstruksi baru atas keadilan, kesetaraan dan masyarakat yang demoktratis. Pendidikan multikultural sangat penting diberikan kepada peserta didik yakni untuk memberikan pengetahuan dan pemahaman baru terkait dinamika multikultur di Indonesia. Melalui pendidikan multikultural peserta didik diharapkan dapat dengan mudah memahami, menguasai, memiliki kompetensi yang baik, bersikap dan menerapkan nilai-nilai demokratis, humanisme dan pluralisme di sekolah dan di luar sekolah. 
Oleh karena itu, perlu menerapkan beberapa prinsip dalam mengimplementasikan pendidikan multikultural di dalam proses pendidikan terutama di sekolah. Pendidikan multikultural harus mampu mempresentasikan pandangan banyak orang dan diintegrasikan dalam sebuah kurikulum di sekolah. Dengan mempertimbangkan beberapa pendekatan dari Banks, yaitu: integrasi materi (content integration), proses pembentukan pengetahuan (knowledge construction process), reduksi prasangka (prejudice reduction), pendidikan/perlakuan pedagogi tanpa pandang bulu (equity pedagogy), dan pemberdayaan budaya sekolah dan struktur sosial (empowering school culture and social structure). Pendekatan itu dapat diterapkan dalam proses pembelajaran dan penerapan kultur di sekolah untuk mendukung pengembangan sistem pendidikan yang multikultural.

\section{DAFTAR PUSTAKA}

Arifin, Ahmad H. 2012. Jurnal Pembangunan Pendidikan: Fondasi dan Aplikasi. Universitas Negeri Yogyakarta.

Banks, James A. (2007). Educating citizens in a multicultural society. New York: Teacher College Press. gavin Kalam Utama.

Indrapangastuti, Dewi. 2014. Praktek dan Problematik Pendidikan Multikultural di SMK. Jurnal pembangunan Pendidikan, Volume 2, 2014 (13-25).

Rosyada, Dede. 2014. Pendidikan Multikultural Sebagai Sebuah Pandangan di Indonesia. Jurnal Sosio Didactia, Volume 1, No. 1, Mei 2014 (1-12).

Sutarno. 2008. Pendidikan Multikultural. Jakarta: Direktorat Jendral Pendidikan Tinggi Departemen Pendidikan Nasional.

Tilaar, H.A.R. 2004. Multikulturalisme: Tantangan-tantangan Global Masa Depan dalam Transformasi Pendidikan Nasional. Jakarta: Grasindo.

Undang-Undang Republik Indonesia Nomor 20 Tahun 2003 Tentang Pendidikan Nasional

Zamroni. (2011). Pendidikan demokrasi pada masyarakat multikultural. Yogyakarta. 